\section{Análise dialógica da argumentação polêmica: uma hipótese geral*}

\author{
Dialogical analysis of the \\ polemic argumentation: $a$ \\ general hypothesis
}

Lucas Nascimento SILVA (UFBA/PPGLinC/FTC) mlucasnascimento@gmail.com

Recebido em: 15 de out. de 2018. Aceito em: 04 de mar. de 2019.

Pesquisa doutoral realizada com fomento da Fundação de Amparo à Pesquisa do Estado da Bahia (FAPESB).
SILVA, Lucas Nascimento. Análise dialógica da argumentação polêmica: uma hipótese geral. Entrepalavras, Fortaleza, v. 9, n. 1, p. 151-169, janabr/2018.

Resumo: Tudo adquire sentido ao ser humano ao redor de "um centro concreto de valores que é pensado, visto, amado" (BAKHTIN, 2010, p. 124). É a partir desse centro de amores que o homem age responsavelmente em relação ao outro, de maneira que a compreensão do dialogismo polêmico tem de ter isso em foco ao visar um sujeito polemizando. Desse modo, é razoável afirmar que $\mathrm{o}$ ato de guerrear polemicamente pressupõe a reação a um valor amado que está ameaçado por um valor contrário, portanto, por um valor que se odeia por ameaçar o que se ama. Na perspectiva de uma análise dialógica da argumentação, resultado do encontro entre Bakhtin e Perelman e Olbrechts-Tyteca, proposta em meu trabalho de doutorado, trago uma reflexão teórica e discuto os fundamentos da hipótese de que a polêmica é um ódio velado aos valores amados do outro, manifestando-se argumentativamente, sobretudo, pela polarização, cujas características particulares vão se delineando no processo argumentativo concreto. A partir dessa hipótese, outras são delineadas e testadas, servindo de dispositivos analíticos para a compreensão da polêmica religiosoafetiva em torno da discussão do Projeto de Lei anti-homofobia, no Senado Federal do Brasil.

Palavras-chave: Dialogismo polêmico. Argumentação. Polêmica. 
V. 9 (1)

151-169

jan-abr

2019

Abstract: Everything acquires meaning to the human being around "a concrete center of values that is thought, seen, loved" (BAKHTIN, 2010, 124). It is from this center of love that man acts responsibly in relation to the other, so that the understanding of polemic dialogism must have this in focus when aiming at a polemizing subject. Thus, it is reasonable to say that the act of warring polemically presupposes a reaction to a beloved value that is threatened by an opposite value, since, by a value one hates to threaten what one loves. In the perspective of a dialogical analysis of the argumentation, a result of the meeting between Bakhtin and Perelman and Olbrechts-Tyteca, proposed in my doctoral work, I bring theoretical reflection, and discuss the foundations of the hypothesis that the polemic is a veiled hatred of loved ones on the other hand, it is argued above all by polarization, whose particular characteristics are delineated in the concrete argumentative process. From this hypothesis others are outlined and tested, serving as analytical devices for the understanding of religious-afective polemic around the discussion of the Anti-Homophobia Bill in the Federal Senate of Brazil.

Keywords: Polemical dialogism. Argumentation. Polemic.

\section{Introdução}

Pensemos bem: se a natureza da linguagem é dialógica, e a dialogia não indica apenas o "diálogo" no sentido comum, mas também o desacordo, o dissenso e a polêmica, então convém pensar que a polêmica não pode ser vista como se estivesse fora da constituição da natureza da linguagem natural, como se ela fosse uma intrusa no banquete dos sentidos ${ }^{1}$. Se é assim, é daí que devemos requerer o digno lugar dos estudos da polêmica à mesa, no campo das Ciências Humanas.

Alguns trabalhos importantes têm surgido para tratar das características da polêmica e de suas possibilidades de análise, a exemplo de Apologie de la polémique de Ruth Amossy (2014). Isso é ótimo. Porém, além disso, precisamos pensar as condições de possibilidade, discursivas e argumentativas, da polêmica: o que leva alguém a polemizar? Ou qual o motivo de uma polêmica?

Tenho pensado a questão a partir do encontro entre o dialogismo de Bakhtin (2010; 2011; 2013), em que parto da Filosofia do ato responsável em direção à Nova Retórica de Chaim Perelman e Lucie Olbrechts-Tyteca (2005), cujo resultado é uma análise dialógica da argumentação. Daí repouso sobre a polêmica entre defensores e opositores do Projeto anti-homofobia (PLC 122/2006), os quais designo, respectivamente, de afetivossexuais reformistas e cristãos tradicionalistas. Fiz isso no doutorado, e aqui trago parte do labor teórico dessa pesquisa (NASCIMENTO, 2018). Assim, pretendo apresentar as bases que sustentam mais diretamente uma hipótese geral, a de que

\footnotetext{
${ }^{1}$ Afinal, a polêmica oferece uma parcela significativa de contribuição na dinâmica dos sentidos, como Dominique Maingueneau já apontou em Sémantique de la polémique (1983) e em Gênese dos discursos ([1984] 2008).
} 
a polêmica é um ódio velado aos valores amados do outro, manifestando-se argumentativamente, sobretudo, pela polarização, cujas características particulares vão se delineando no processo argumentativo concreto. Fazendo isso, trago à baila o dialogismo polêmico.

Pensar a polêmica nesses termos é ver que o ser humano vive em um mundo axiológico e responde a valores. Sob essa perspectiva, a proposta é olhar a polêmica a partir de sua própria lógica, não impor uma lógica da "razão" alheia, mas a do sentimento gerador, afinal, estamos no âmbito da lógica dos valores. Assim, pode-se compreender como em uma polêmica tem-se o efeito do sentido do ódio, como se as pessoas ali se odiassem de fato. Eis a questão colocada pelo pronunciamento de um dos argumentantes da polêmica supracitada:

[1] Mas nós, que somos políticos, não podemos permitir que pessoas que estão buscando a mesma coisa nesta sessão estejam em lados tão separados, tão opostos. Parece que nos odiamos! Não nos odiamos, isso é um absurdo que não pode ficar desta maneira ([Sr. Crivella], BRASIL. CDH, 2011, p. 21).

Ora, em que sentido é possível compreender esse efeito de ódio, se muitos que entram numa polêmica acirrada são, muitas vezes, amigos, parentes, partidários de um mesmo viés político? Razão disso é porque há um ódio no ato de polemizar. Ódio aos valores do outro que, muitas vezes, se confunde com ódio à pessoa² e, por vezes, também o é, porque há uma interação entre a pessoa e seus atos, como asseguram Perelman e Olbrechts-Tyteca (2005).

Isso remete para uma ordem de valores que o sujeito abraça e outros dos quais se distancia, o que Santo Agostinho chamou de ordo amoris, cuja retomada o filósofo alemão Max Scheler (2001; 2008) faz para mostrar que é possível observar quais valores determinada pessoa ama ou odeia, conhecendo-a através dessas preferências, digo, a partir daquilo que o sujeito antipatiza ou simpatiza, como diz Bakhtin (2011).

Quando se considera certa lógica dos valores, rejeita-se a pretensão de querer explicar as relações humanas pela linguagem e lógica racionalistas. Abre-se, por outro lado, à logique du couer, afinal, como disse Pascal, "o coração tem suas razões, que a razão não conhece: sabe-se disso em mil coisas" (2005, p. 164 [423]). Isso jamais significa diminuir o papel do racional, todavia, significa dá-lhe o devido lugar nas relações linguageiras, em um bom espírito aristotélico, que a modernidade infelizmente cuidou de enfermar.

\footnotetext{
${ }^{2}$ Aqui ódio não deve ser compreendido como ódio à pessoa, mas, como nos mostra Scheler (1942), ódio aos valores que a pessoa compartilha.
} 
V. 9 (1) 151-169 jan-abr 2019

Poucos ${ }^{3}$ estudiosos trabalham um olhar profundamente dialógico sobre a polêmica, de modo que os estudos bakhtinianos do dialogismo polêmico nem são citados pelos "renomados teóricos" que estudam o fenômeno, a exemplo de Amossy (2014). No entanto, sob o prisma dialógico-argumentativo, a vontade de compreensão levou-me a trabalhar sob hipótese da polêmica como ódio velado aos valores do outro. Para tanto, situarei brevemente na primeira seção os estudos polêmicos, depois, deter-me-ei na noção de polêmica em Bakhtin, para, em seguida, voltar a fim de argumentar melhor em favor dessa hipótese geral.

\section{O estado da polêmica: retóricas do dissenso}

Combate. Guerra. Polêmica. Termos que remetem a Pólemos, uma daemon (divindade) que personificava a guerra. Em Heráclito de Éfeso, pólemos é o princípio de tudo, da guerra, princípio incriado do que é e pode vir a ser. Logo, "a guerra [combate] é pai de tudo, rei de tudo" 4 , ela é a harmonia dos contrários. Ainda assim, mesmo que a guerra fosse marcada pela violência (por Hybris, a esposa de Pólemos), ela continha em si certa ética da guerra, a qual se estende de alguma forma à polêmica (NEVES, 2017).

Observemos que pólemos está na etimologia da língua grega "polemikos", não é à toa que este termo relaciona-se a uma série de metáforas, quais sejam: bateria argumentativa, jogo oratório, estratégia discursiva, jogo de massacre e guerrilha com as palavras. Ou melhor, "polêmica" é uma metáfora lexicalizada: "é uma guerra metafórica, uma 'guerre de plume' (guerra de pena)" (ORECCHIONI, 1979, p. 4-5).

A polêmica é uma guerra profunda de valores, que remete a um conflito de lógicas e cosmovisões, a qual está associada a ares e a eris, o deus da guerra e a deusa da discórdia, que nos legou o termo erística. Eris ${ }^{6}$, a filha da Noite e irmã de Ares, o deus da guerra ao qual ela

\footnotetext{
3 Aqui chamo atenção para os trabalhos de Brait e Machado (2011), sobretudo de Elmo dos Santos (2012) e Simone Veloso (2011), que trabalham especificamente com o tema.

4 Fragmentos 53: "De todas as coisas a guerra é pai, de todas as coisas é senhor; a uns mostrou deuses, a outros, homens; de uns fez escravos, de outros, livres". E fragmento 80: "Se é necessário a guerra (pólemon), sendo união (xúnon), e a justiça, sendo conflito (érin), é também necessidade tudo o que vem a ser segundo o conflito" (HERÁCLITO, 2002).

5 Tradução livre do autor. Texto original: "c'est une guerre métaphorique, une 'guerre de plume"".

6 "Fille de la Nuit et soeur d'Arès, le dieu de la guerre qu'elle accompagne sur les camps de bataille. Eris signifie querele, discorde - son nom latim est Discordia, c'est-à-dire "désaccord, dissentiment violent qui oppose les personnes entre eles et les dresse les unes contre les autres" (Larousse) (AMOSSY, 2014, p. 20).
} 
acompanhava. Não à toa, fala-se na retórica de arsenal de argumentos; por exemplo, Marc Angenot (2008), ao analisar as polêmicas e as lógicas da modernidade, falará de arsenal argumentativo como conjunto de argumentos mobilizados, os quais aparecem como se fossem munições para a batalha argumentativa.

Ao olhar, então, para a realidade das relações dialógicas, uma análise argumentativa não pode se furtar de ver a pluralidade de vozes que estão em diálogo e conflito. Por essa razão, uma análise dialógica da argumentação pode se ocupar tanto dos acordos como dos desacordos, dos mais superficiais aos mais profundos. Pontuarei assim, breve e seletivamente, os estudos da polêmica pela perspectiva da retórica argumentativa e da análise do discurso.

Majoritariamente, os estudos contemporâneos da argumentação não se interessam de modo central pela polêmica, esta aparece marginalmente nas finalidades, além de a reduzirem a uma forma de debate rico em paralogismos. Porém, o que de fato influi tal direcionamento é o privilégio que o consenso goza ante as questões argumentativas, e ele urge como ideal. No entanto, não é que se deva colocar o dissenso como ideal argumentativo, mas compreender que ele faz parte da natureza argumentativa das relações humanas, pois diz respeito à relação entre o eu e o outro, da gestão das identidades e diferenças entre os sujeitos. Nesse sentido, é preciso olhar para a realidade dos fatos humanos e compreender sua importância, sobretudo em uma democracia.

Christian Plantin (2003), no excelente artigo "Des polémistes aux polémiqueurs", reunido na obra La parole polémique, em 2003, mostra três paradigmas nos estudos argumentativos e como eles tratam a polêmica. No primeiro, que é o retórico-enunciativo, inaugurado por Perelman e Olbrechts-Tyteca ([1958] 2005)7, cultivado também por Toulmin ([1958] 2006), não aparece nas obras de ambos o termo "polêmica". O segundo paradigma é o dialético, que inclui desde Hamblim, de 1970, até a pragmadialética de Van Eemeron \& Grootendorst (Fundamentals of argumentation theory, 1996). E a terceira perspectiva diz respeito à abordagem estrutural de Ducrot, a qual caracteriza a atitude polêmica como manifestação de agressividade constitutiva de um bom debatedor.

\footnotetext{
${ }^{7}$ Esta centra-se em técnicas que permitem provocar ou intensificar a adesão às teses que se apresentam à aprovação. Tal perspectiva é herdeira da tradição aristotélica tendente a privilegiar o acordo e um debate controlado pelas regras do logos para o debate deliberativo. Retomo algumas questões da tradição para voltar então, mais à frente, à nova retórica.
} 
V. 9 (1)

151-169

jan-abr

2019

Pode-se dizer que historicamente a retórica tem a vocação não apenas para o consenso, mas, sobretudo, para compreender e gerir o dissenso. No entanto, tal gestão, ao visar, de certo ângulo, ao bem da comunidade e aos objetivos públicos, fez da retórica um instrumento para munir os cidadãos a fim de que, por meio da troca verbal, pudessem negociar as diferenças e chegar a um acordo que levasse à ação coletiva. Sendo assim, é na busca desse acordo que a deliberação intervém, cuja materialização se dá nas modalidades de discursos e de debates políticos. Nesse sentido, esse gênero retórico deve estar sob os critérios da razão, ou como assegura Amossy: "Ela é, por definição, o trabalho do logos, ou seja, a fala como discurso e razão"s (2014, p. 19). Mesmo que no jogo do debate deliberativo entre em cena o ethos e o pathos, a deliberação deve ser conduzida por critérios racionais para resolver os conflitos de opiniões por meio da troca verbal regrada.

Quanto à nova retórica, não se pode negar que seu ideal seja o acordo sobre o plausível e o aceitável, pois esse seria a contenção de ondas de irracionalidade e de violência, como as vistas na Europa na primeira metade do século XX. Assim, a pedra de toque da racionalidade retórica torna-se o acordo, mas o problema disso parece significar, como argumenta Amossy, que "o dissenso deve ser superado a todo custo, sob pena de falhar aos critérios da razão e de fazer a comunidade afundar na discórdia, na divisão e, até mesmo, na luta armada" 9 (2014, p. 22). Isso se torna um problema, porque ao se ter uma ciência com certo ideal, passa-se a não enxergar nada além dele, ela se torna cega para os fenômenos que fogem ao ideal. Por conta disso, a nova retórica não contempla analiticamente os tipos de interação que não sejam possíveis de conduzir a um acordo. Despreza, por assim dizer, a erística, vinculando-a ao debate, e exalta a heurística, cultivada na discussão racional, a qual serviria como "instrumento ideal para chegar a conclusões objetivamente válidas" (PERELMAN; OLBRECHTS-TYTECA, 2005, p. 42).

Sabe-se que Perelman funda sua retórica sobre a lógica dos valores, o que é algo muito importante. Contudo, em certos aspectos, ainda preserva alguns ranços de uma visão racionalista ${ }^{10}$ no sentido

8 Tradução livre do autor. Texto original: "elle est par définition l'oeuvre de logos, c'est-à-dire de la parole comme discours et raison".

9 Tradução livre do autor. Texto original: "le dissensos doit être surmonté à tout prix, sous peine de faillir aux critères de a raison et de faire sombrer la communauté dans la discorde, la division, voire la lutte armée".

${ }^{10}$ Racionalista pode ser compreendido tanto numa perspectiva legada por Descartes, quanto 
de que seja sobre um acordo "racional" que a retórica deve repousar para ajudar a estancar a violência. Em alguns contextos, isso se aplica. No entanto, ao estender as análises para relações mais complexas, esse ideal razoável, aplicado enquanto dispositivo de análise, torna-se pouco razoável e míope, porque essa distinção só pode ser claramente delineada na perspectiva de um quadro institucional, em que haja papéis nitidamente divididos e as intenções dos debatedores explicitadas (AMOSSY, 2014). Assim, julgo que o problema parece não dizer respeito ao ideal em si, mas quando esse se torna limitante no plano da compreensão das relações argumentativas. Logo, nos termos de Angenot, "não se pode construir uma ciência partindo de uma eficácia ideal, a persuasão, sendo que ela ocorre apenas excepcionalmente" (2015, p. 128).

Por essa razão, o encontro epistemológico entre Bakhtin e Perelman é produtivo, cujo evento epistemológico resulta na contribuição de ambas as teorias em que se pode colocar o acordo e o desacordo como fenômenos das relações dialógicas. Estas vão desde o plano da consciência subjetiva, que se constitui socialmente, às relações sociais mais complexas, as quais podem ser estudadas remetendo ao campo discursivo, a partir dos gêneros em que os enunciados são produzidos.

Ora, muitos têm sido os estudiosos da "polêmica" em suas distintas designações, aqui, apenas para lembrar três importantes nomes, com os quais faço diálogos, quais sejam: Dominique Maingueneau (1983; 2008), em La sémantique de la polémique e Gênese dos discursos, Marc Angenot, em seu La parole pamphlétaire” (1982) e Dialogues de sourds (2008) e Ruth Amossy, em sua apologia de la polemique (2014). É importante dizer que, de certa maneira, todos tiveram alguma influência de Bakhtin, e, em algum nível, de Perelman no que se refere à argumentação (NASCIMENTO, 2018).

\section{O dialogismo polêmico: Dostoiévski e Bakhtin}

"A natureza dos seres humanos é dialógica" (CLARK, HOLQUIST, 2004, p. 107), e nisso inclui ser também polêmica. A razão já disse, porém repito, o homem é um ser que ama e odeia valores. Nas obras de Dostoiévski, o que temos é a presença de personagens que se amam e se odeiam, uma consonância e um conflito de vozes 
V. 9 (1)

151-169

jan-abr

2019

e cosmovisões que apontam para mundos irreconciliáveis. Isso faz o sujeito ir de um discurso bivocal a uma polêmica aberta, como bem descreve Bakhtin (2013), de maneira que a própria presença alheia incomoda o eu, modificando a estrutura interna de seu discurso. Dessa forma, é razoável considerar que Dostoiévski brinda-nos não apenas com o gênero romance polifônico, mas também com seus personagens, com os quais nos apresenta a natureza discursiva de um homem polêmico, este que ama e odeia certa ordem de valores e, portanto, ao enunciar, tal ato determina a estrutura e os sentidos de seus enunciados.

O estudo da poética de Dostoiévski é um importante suporte para se compreender a questão do dissenso da modernidade para cá. A maneira como o escritor russo põe em interação seus personagens faz aparecer um cenário em que vozes, não apenas diferentes, mas divergentes, coexistem, de modo que tal pluralidade no plano artístico-literário é algo singular às obras dostoievskianas. Bakhtin, em Problemas da poética de Dostoiévski, assegura que "A multiplicidade de vozes e consciências independentes e imiscíveis e a autêntica polifonia de vozes plenivalentes ${ }^{11}$ constituem, de fato, a peculiaridade fundamental dos romances de Dostoiévski” (BAKHTIN, 2013, p. 4, itálico do autor), sendo o escritor russo do século XIX o criador de um gênero romanesco novo, o romance polifônico.

Tal criação romanesca não foi inspirada apenas em questões subjetivas. Em boa medida, Dostoiévski encontrou a multiplicidade de planos, de mundos e a contrariedade ${ }^{12}$ no universo social objetivo, proporcionado pelo estado da sociedade russa de então. Como diria Bakhtin (2013, p. 30), "a própria época tornou possível o romance polifônico". E esse mundo de Dostoiévski é, como afirma Otto Kaus (apud BAKHTIN, 2013, p. 20), "a expressão mais pura e mais autêntica do espírito do capitalismo", dado que este pôs em coexistência múltiplos planos. Isso porque na Rússia, onde o capitalismo teve um crescimento acentuado - mas que, inicialmente, pouco mexeu na diversidade de mundos e dos grupos sociais -, entrou em choque as diferentes visões de mundo dos indivíduos numa unidade contraditória. Há, portanto, o

\footnotetext{
11 "Isto é, plenas de valor, que mantêm com as outras vozes do discurso uma relação de absoluta igualdade como participantes do grande diálogo" (BAKHTIN, 2013, p. 4, em nota).

${ }^{12}$ Dostoiévski participou dessa contrariedade enquanto sujeito que fazia sua trajetória de formação subjetiva e espiritual, contudo essa experiência individual não recebeu tradução imediata para sua obra numa expressão monológica, todavia o ajudou a compreender em profundidade as largas contradições entre os homens e não entre as ideias numa consciência. (BAKHTIN, 2013, p. 30-31).
} 
surgimento de choques de formações sociais, "entre sistema que antes não mantinha qualquer contato entre si" (BAKHTIN, 2013, p. 38), e que, na sociedade capitalista, começa a se encontrar e a se confrontar perfazendo uma complexidade de dissensos e polêmicas.

O dialogismo polêmico é uma categoria que se faz presente, ao menos de maneira implícita, nas diferentes obras de Bakhtin, desde a noção de ato ético, passando pela relação entre o autor e o herói, inclusa como gênero bivocal, e se formos ao seu Círculo, ela está lá, enquanto discurso bivocal, em Volochínov (BAKHTIN, 2014). No entanto, ela só vem ganhar esmero no famoso capítulo "O discurso em Dostoiévski" de Problemas da poética de Dostoiévski, no qual, o autor, ao dar mais um importante passo na jornada de argumentar em prol da existência de um gênero romance polifônico em Dostoiévski, oferece aos estudiosos da linguagem uma gama de conceitos preciosos, que não foram retirados de alguma arquitetura conceitual abstrata, todavia das análises das novelas do grande literato russo.

Ademais, é importante reafirmar que essas noções têm servido tanto às análises dialógicas, literárias, quanto às análises de discurso e à linguística da enunciação ${ }^{13}$, quais sejam: o discurso bivocal, em que as palavras do outro, introduzidas na fala do sujeito são revestidas de algo novo, a partir da compreensão e avaliação do sujeito, o qual pode se manifestar como discurso bivocal de orientação única - a estilização, a narração do narrador, o Icherzählung-, e também como discurso bivocal de orientação vária, - a paródia, a narração parodística, o Icherzählung parodístico ou qualquer transmissão da palavra do outro com acento (BAKHTIN, 2013, p. 228). Contudo, sem deixar de recorrer a essas noções, chamo atenção para estas: a polêmica velada interna e a polêmica aberta. Portanto, a polêmica é um discurso bivocalizado.

Na polêmica velada, o sujeito reveste as palavras do outro com suas próprias intenções, "que são estranhas e hostis a elas" (BAKHTIN, 2013, p. 223). A respeito disso, que pode também ser chamado de réplica dialógica, Bakhtin diz: "a palavra do outro permanece fora dos limites do discurso do autor, mas esse discurso o leva em conta e a ela se refere" (2013, p. 223). De maneira que "a palavra do outro não se reproduz sem nova interpretação, mas age, influi e de um modo ou de outro, determina a palavra do autor, permanecendo ela mesma fora desta", havendo, por assim dizer, uma relação tensiva com a visada do outro, com os sentidos que o outro compartilha a respeito de um mesmo objeto.

\footnotetext{
${ }^{13}$ Ao me lembrar, Ducrot (1987), Ducrot e Anscombre ([1988] 1994), Rabatel (2016).
} 
V. 9 (1)

151-169

jan-abr

2019

Na polêmica velada, o discurso do autor está orientado para o seu objeto, como qualquer outro discurso; neste caso, porém, qualquer afirmação sobre o objeto é construída de maneira que, além de resguardar seu próprio sentido objetivo, ela possa atacar polemicamente o discurso do outro sobre o mesmo assunto e a afirmação do outro sobre o mesmo objeto. Orientado para o seu objeto, o discurso se choca no próprio objeto com o discurso do outro. Este último não se reproduz é subentendido; a estrutura do discurso seria inteiramente distinta se não houvesse essa reação ao discurso subentendido do outro. (BAKHTIN, 2013, p. 225).

Não é sem sentido que a reação à palavra do outro modifica a estrutura do enunciado, de maneira que "o discurso sente tensamente ao seu lado o discurso do outro falando do mesmo objeto, e a sensação da presença desse discurso lhe determina a estrutura" (BAKHTIN, 2013, p. 225). Vê-se que esse tipo de discurso polêmico é muito peculiar no linguajar do cotidiano, pois essa variedade de uso da língua incorpora todas alfinetadas e indiretas dirigidas. Dito de outro modo, "a maneira individual pela qual o homem constrói seu discurso é determinada consideravelmente pela sua capacidade inata de sentir a palavra do outro e os meios de reagir diante dela" (BAKHTIN, 2013, p. 225); e na literatura, tal discurso interno polêmico é singular para a formação do estilo, sobretudo os de Dostoiévski, como mostra Bakhtin (2013), extensivamente, na análise dos romances "Gente Pobre", "O Duplo" e "Memórias do Subsolo".

Após ter analisado "O duplo", de 1846, Bakhtin (2013) explora as noções de alteridade constitutiva, na dimensão dialógica que constitui a linguagem no embate com a vida. No item 2, ele observa que nas confissões do homem do subsolo há "a dialogização interior extrema e patente: nela não há literalmente nenhuma palavra monologicamente firme, não decomposta" (BAKHTIN, 2013, p. 263). Assim, ele percebe que "o herói já começa a crispar-se, a mudar de voz sob a influência da palavra antecipável do outro, com a qual ele entra em polêmica interior sumamente tensa desde o começo" (BAKHTIN, 2013, p. 263). Analisando as primeiras palavras da confissão, o filósofo russo logo observa que há uma polêmica velada com outro:

Nas primeiras palavras da confissão, a polêmica interior com o outro é velada. Mas a palavra do outro está presente de modo invisível, determinando de dentro para fora o estilo do discurso. Contudo, no meio do primeiro parágrafo a polêmica irrompe numa polêmica aberta: a réplica antecipável do outro se insere na narração, é verdade que em forma ainda atenuada. 'Não, se não quero me tratar é apenas por uma questão de raiva. Certamente não compreendereis isto. Ora, eu compreendo'. (BAKHTIN, 2013, p. 264). 
Na polêmica velada o discurso do outro é atacado apenas indiretamente, nomeando-o, representando-o, enunciando-o, de maneira que "a ideia do outro só não entra 'pessoalmente' no discurso, apenas se refletindo neste e determinando-lhe o tom e os sentidos" (SANTOS, 2012, p. 44). Já na polêmica aberta, no entanto, como mostra a análise de Bakhtin (2013) acima, o discurso do outro converte-se diretamente em objeto, e tal qual explica o estudioso do dialogismo polêmico Elmo dos Santos (2012, p. 45), os “... enunciados estão firmemente orientados para o discurso refutável do outro, e podem se materializar textualmente em uma palavra ou na totalidade de um texto".

Sendo assim, pode haver um continuum que vai da polêmica velada até estourar numa polêmica aberta. Sobre isso, Bakhtin (2013, p. 273) analisa Memórias do subsolo e assegura a respeito do herói: "suas palavras sobre o universo são veladas e abertamente polêmicas; e polemizam não somente com as outras pessoas, com outras ideologias, mas também com o próprio objeto do seu pensamento - o universo e a sua organização". Brait e Machado (2011) nos fazem acompanhar o diálogo entre Bakhtin e Dostóievski, no subsolo. Lá, vê-se uma consciência permeada de vozes em conflito, de maneira que "em cada ideia sobre eles há uma luta entre vozes, apreciações, pontos de vista. Em tudo ele percebe antes de mais nada a vontade do outro, que predetermina a sua" (BAKHTIN, 2013, p. 273, itálico do autor).

Não é razoável tomar a polêmica sem olhar para seus níveis de intensidade. No conjunto da obra de Bakhtin, ela aparece em níveis diferentes de intensidade, tonalidade, acento, cuja aproximação ou distanciamento entre os discursos aponta, por assim dizer, para seu caráter de polêmica velada, aberta, interna, ou hostil, ou seja, a intensidade determina suas submodalidades. Nessa variedade é que se caracteriza o dialogismo polêmico, de maneira que, ao se compreender a polêmica em Bakhtin, é possível dizer que ela também é ética, pois o sujeito age a partir de seu lugar no mundo, de maneira responsiva e não menos responsável, embora nem sempre tenha consciência disso. Nesse sentido, a polêmica não é vista com desprezo, mas como constitutiva da própria relação do eu com seu outro, cujo estudo é possível por meio do enunciado concreto. Ou seja, em um enunciado polêmico, pode-se observar como a palavra do outro é inferida e traduzida pelo eu, bem como seus efeitos de sentido. 
V. 9 (1)

151-169

jan-abr

2019

Ainda é necessário aprofundar os estudos sobre esse dialogismo polêmico. Como nos mostra Elmo dos Santos (2012), é preciso compreender como, em um mesmo objeto, dois discursos se chocam. Neste sentido, nada melhor do que voltar a dialogar com quem o próprio Bakhtin dialogou para construir sua arquitetônica dialógica. Por isso, volto a Max Scheler $(2001,2008)$ para tentar lançar luz sobre o motivo da polêmica, apontando, mais claramente, por que polemizar também é um ato ético.

\section{Polêmica como ética: por uma definição}

Edificar noções sobre a ética dialógica é construir sobre uma arquitetônica que contemple a realidade sem tentar sufocá-la em esquematizações, porque, como nos lembra Bakhtin, "somente uma atenção amorosamente interessada pode desenvolver uma força muito intensa para abraçar e manter a diversidade concreta do existir, sem empobrecê-lo e sem esquematizá-lo" (2010, p. 128). Assim, pode-se pensar que o ato polêmico também se dá no movimento de empatia ativa (vzhivanie, do russo); isso acontece uma vez que o eu entra no mundo do outro, identifica seus valores, contudo, ao mesmo tempo, não perde seu lugar de fora, sua exotopia. Razão pela qual os valores compreendidos são objeto de ódio, pois são incompatíveis ou contrários aos valores amados de sua extralocalização, gerando uma resposta repulsiva, uma objeção hostil, resultante do mesmo bem que é valorado de maneira diferente pelos sujeitos, afinal, como diz Bakhtin (2013), visões diferentes podem se confrontar em um mesmo objeto.

Assim, nesse encontro epistemológico entre dialogismo e retórica argumentativa, trago a hipótese que submeti a testes, qual seja, a de que a polêmica é um ódio velado aos valores amados do outro, manifestando-se argumentativamente, sobretudo, pela polarização, cujas características particulares vão se delineando no processo argumentativo concreto, como a desqualificação do outro, a violência verbal e elementos patêmicos manifestos, como a diabolização. Chamo atenção para o fato de a própria polarização já pressupor uma dicotomização, a qual remete a um confronto de teses antagônicas, como aponta Ruth Amossy (2014). Mas, nessa perspectiva, o que seria então o ódio?

O ódio é o outro do amor. Todo ódio a um valor pressupõe um valor amado que lhe é contrário. A lógica do ódio está no fato de que 
"todo ato de ódio assenta num ato de amor, sem o qual ele careceria de sentido"14 (SCHELER, 2008, p. 66). Portanto, ambos se distanciam da zona de indiferença, na medida em que ambos se interessam pelos objetos portadores de valor, cujo interesse originalmente está orientado para o amor, onde de lá se vislumbra seu outro e o odeia. Isto pode ficar bem compreendido na frase de Bossuet, citada por Scheler: "o ódio que se sente contra qualquer coisa procede apenas do amor que por outra se sente; detesto a doença tão somente porque amo a saúde"15 (2008, p. 67-68).

Em Scheler e em Bakhtin, de fato, é o amor que é produtivo, nele que até mesmo o ódio se assenta, como afirma Bakhtin, "somente o amor pode ser esteticamente produtivo, somente em correlação com quem se ama é possível a plenitude da diversidade" (2010, p. 129). Portanto, a ética da polêmica assenta-se não sobre o ódio em si mesmo, contudo sobre o ódio enquanto o outro do amor. Por exemplo, como mostro em análise, o afetivossexual pró-plc122 polemiza com o religioso cristão porque vê seu valor amado ameaçado, por outro lado, o religioso polemiza com o outro, o afetivossexual, porque vê no valor deste uma ameaça a seu valor amado (NASCIMENTO, 2018).

$\mathrm{Na}$ maioria das vezes, toma-se a noção de ódio numa perspectiva racionalista, como algo inteiramente negativo, no entanto não é bem assim. Com a intenção de trazer seriedade ao estudo da polêmica, tenta-se afastá-la do ódio e tomar a explosão de ódio como um dos elementos eventuais da polêmica, como no caso da diabolização do outro enquanto reação de medo ou ódio, tal qual coloca Amossy (2017, p. 60 $)^{16}$. Mas isso é apenas uma manifestação radical do ódio, de maneira que o outro é diabolizado porque ele é aquele que ameaça o meu bem, o que para mim é bom, contudo para o outro é mal, por isso ele tenta atacá-lo e somente o contrário do bem pode querer destruí-lo, portanto o mal, o diabólico. Nesse processo, que se chega à diabolização, há o funcionamento do argumentum ad odium que, segundo Angenot, "designa o fato de tornar odioso aos olhos dos valores fundamentais ou da decência elementar as ideias do oponente" (2015, p. 160).

\footnotetext{
${ }^{14}$ Tradução livre do autor. Texto original: "Todo acto de odio se halla fundado en um acto de amor, sin el cual carecería aquél de sentido".

15 Tradução livre do autor. Texto original: "El odio que se experimenta contra qualquier cosa procede tan sólo del amor que se siente por otra; odio a la enfermedad tan sólo porque amo la salud".

${ }^{16}$ Diz: "encontramos tentativas de diabolização ou de apresentação do adversário com traços do mal absoluto, as quais comportam uma incitação ao medo, ao mesmo tempo em que ao ódio" (2017, p. 60).
} 
v. 9 (1) 151-169 jan-abr 2019

Para além disso, o ódio é um sentimento, cujo fundamento emocional é a raiva ${ }^{17}$, a qual está na base da indignação contra as injustiças, como a discriminação, o racismo, a homofobia etc. Logo, o ódio, enquanto sentimento e emoção ${ }^{18}$, tem sua razão de ser, não pode ser tomado como meramente incontrolável, imprevisível e irracional, como nos mostra Robert Solomon (2015) a respeito da raiva, em sua famosa obra Fiéis às nossas emoções. E, aqui, pode-se lembrar também dos estudos do neurocientista português António Damásio (1999), sobretudo, em 0 erro de Descartes: a razão das emoções, o que também me faz remeter ao analista de discurso Christian Plantin (2011), em sua obra Les bonnes raisons des émotions.

Ora, o objeto odiado é representado por palavras passíveis de nelas se ver a tensão polêmica. Por exemplo, a palavra "homofobia" é portadora de valores odiados por um grupo e amados por outro grupo (NASCIMENTO, 2018). Como isso acontece? Scheler argumenta que "precisamente neste fato de que o amor é um movimento na direção do 'ser mais elevado do valor', é o seu significado criativo (já reconhecido igualmente por Platão)" ${ }_{19}$ (SCHELER, 1942, p. 222). Assim, o ódio é esse movimento em tomar o mais alto valor como o mais baixo. Nesse sentido, a polêmica se dá no fato de um sujeito, individual ou coletivo, amar alguns valores e odiar seus opostos, porquanto todos os que ele percebe que encarnam aqueles valores, ele tende a amá-los. Contudo, todos os que encarnam os valores que ele odeia ${ }^{20}$, não há argumentos que façam amá-los, porque não é uma questão meramente racional, de argumentos, mas envolve uma razão do sentimento, uma lógica do

\footnotetext{
${ }_{17}$ Solomon defende que "a raiva é uma emoção hostil, o que significa dizer que tem uma atitude (ou avaliação) negativa em relação ao seu objeto, a outra pessoa" (2015, p. 282), ela "é, basicamente, um julgamento de que alguém foi prejudicado ou ofendido" (2015, p. 39). A raiva em si não é negativa, mas pode o ser: "Depende. Quem está com raiva, de quem e por quê?". A questão é que ela pode ser justificada, o que se chama de "indignação moral" (2015, p. 282). O ódio seria, nessa perspectiva, uma raiva prolongada (2015, p. 39), cujos contornos não são simples de delinear, de maneira que optarei pela compreensão de tomar como se manifesta o ódio aos valores do outro, deixando esses detalhes para os neurocientistas.
}

${ }^{18}$ É importante dizer que sentimentos e emoções são definidos de maneira diferente. Para Solomon, "sentimentos cobrem um território muito maior do que emoções". Mas para ele, emoções também são sentimentos, "desde que isto não seja considerado uma definição de emoção e com a condição de que não se suponha, a partir daí, que as emoções devem ser inarticuladas" (2015, p. 226).

19 Tradução livre do autor. Texto original: "Justamente en este hecho de que el amor sea um movimento em la dirección del 'ser-más-alto del valor' estriba su significación creadora (ya reconocida igualmente por Platón)".

${ }^{20}$ Mas é importante compreender que esse ódio nem sempre é produzido e levado a cabo pela pessoa que odeia, mas, muitas vezes, por agremiações a que ela pertence, nesse sentido, o ódio a outrem como fenômeno de grupo, de classe, de massa, de campo etc. 
afeto daquela pessoa, espírito, grupo ou campo discursivo. Sobre essa relação de ódio, Aristóteles, na Retórica, ao versar sobre a amizade e a inimizade, dirá: "basta supormos que uma pessoa tem tal ou tal caráter para a odiarmos" (II, 4, 1382 a). Com isso, o amor envolve aproximação, afetos simpáticos, já o ódio envolve distanciamento e afetos antipáticos.

Isso faz sentido com a objeção de Marc Angenot (2008), qual seja, os homens argumentam constantemente, mas quase nunca se persuadem. De modo que isso não tem a ver com o conteúdo dos argumentos, meramente com a diferença da percepção de mundo, contudo tem a ver com as divergentes maneiras de conceber as regras "lógicas"21, por isso os homens frequentemente acham os outros irracionais.

Aprofundar, portanto, essa noção de polêmica a partir dessa perspectiva permite pensar o fato de uma pessoa ao amar determinados valores, pode considerá-los tão altos que não se presta atenção nas possíveis contradições em bens, pessoas, grupos ou procedimentos que portam aqueles valores. Isso não significa dizer que o amor por aquele valor seja cego, como comumente se diz que "o amor é cego", mas a questão se explica de outra maneira, é que o sujeito se deslumbra tanto com o valor portado pelo bem que deixa os defeitos de lado (SCHELER, 1942). Portanto, não é uma questão de cegueira, todavia de foco. O contrário acontece quando se vislumbra um valor odiado, a tendência é não reconhecer o que há de positivo no portador do valor negativo, há uma indisposição afetiva. Por isso, quando se ama determinado valor, dele se aproxima, o sujeito abre-se para possível persuasão se há uma congratulação com aquele valor. Quando se odeia, não há abertura para persuasão nem compreensão, dele se afasta, nesse sentido, haveria uma zona de persuasão possível.

Nesse movimento, não se pode falar que a polêmica é uma atitude de indiferença, mas na polêmica há um envolvimento emocional profundo entre o eu e o outro. Todavia, por basear-se no ódio ao valor do outro, isso compromete a interpretação e compreensão do mundo do outro, porém não

\footnotetext{
${ }^{21}$ Lógica aqui diz respeito ao que em perspectivas mentalistas definiram como "maneiras de pensar, denkungstart, Outillages mentaux, Styles of thought, (os cientistas políticos americanos conceberam, por exemplo, o que chamam de 'estilo paranoico', 'um modo social de pensamento' [...], Gedachtenvormen (em Johan Huizing), episteme (quando a palavra é deslocada do estudo das disciplinas esotéricas para o estudo da doxa e dos discursos públicos)" (ANGENOT, 2015, p. 94-95). Pode-se falar ainda de "espírito" ou como faz Sowell (2012) de "visão". Assim, a noção de lógica aqui diz respeito à coerência e à fiabilidade. "Coerência... não pode ser confundida com a racionalidade: um sistema delirante ou fundado em um pressuposto absurdo pode ser muito coerente" (ANGENOT, 2015, p. 95).
} 
V. 9 (1)

151-169

jan-abr

2019

é porque o outro não seja compreensível, mas porque os seus valores são vistos como absurdos. Ora, se tivermos em vista o que Aristóteles diz: "os juízos que emitimos variam conforme sentimos tristeza ou alegria, amor ou ódio" (Retórica, I, 2, 1356a), então, pode-se ver que a valoração se dá a partir do estado afetivo do eu. Por exemplo, para os afetivossexuais reformistas é um absurdo o discurso de que a homossexualidade é pecado, de maneira que é preciso criminalizar a causa profunda da homofobia. Por outro lado, tal tentativa é absurda, ferindo a liberdade religiosa e de expressão, contraargumentam os cristãos tradicionalistas (NASCIMENTO, 2018).

Se é possível considerar que a polêmica faz parte de um continuum desde uma modalidade argumentativa negociada até a polêmica no outro extremo, tal qual argumenta Amossy (2014), gostaria de colocar essa questão nos termos acima e ver sua dialogicidade, pois isso me permite afirmar com certo grau de razoabilidade que o homem é, em sua condição humana, um ser polêmico, porque é um ser dialógico que ama e odeia. Algumas organizações sociais, é claro, potencializaram a polemicidade, a exemplo das sociedades capitalistas modernas; outras, nem tanto, mas a própria existência de polêmicas ao longo da história corrobora essa perspectiva.

O que irá determinar se estamos ante um discurso polêmico, ou não, é a maneira como o posicionamento central se comporta ante o que refuta. Com isso, pode-se ver como os posicionamentos contribuem para formar polos opostos que se agrupam compondo campos a se atualizarem a partir de entidades de outras polêmicas, o que já deriva, apenas para citar, a hipótese de evento polêmico ${ }^{22}$. Além disso, é preciso considerar que, em outro momento, em outro lugar, em outro gênero, aquele mesmo posicionamento poderia ser profundamente polêmico. Então, em um plano universal da relação interdiscursiva, todo posicionamento é polêmico. Mas isso não nos ajuda muito a pensar a questão, contudo nos prepara para adotar uma visão adequada para se pensar o problema. E faço isso propondo as noções de evento polêmico, ato polêmico ${ }^{23}$ e microato polêmico ${ }^{24}$, a respeito das quais não é possível entrar em detalhes aqui.

22 "o evento polêmico é o encontro de posicionamentos polêmicos, fundantes de dois campos discursivos antagônicos, responsáveis por atualizar entidades de outras polêmicas, ao disputarem os sentidos de um mesmo objeto do discurso em um dado cronotopo" (NASCIMENTO, 2018, p. 204).

23 Ato polêmico pode-se compreender "os acordos, os argumentos e os posicionamentos mobilizados no processo argumentativo, imantados pelo evento polêmico". (NASCIMENTO, 2018, p. 209)

${ }^{24}$ Pode ser uma palavra, ou expressão valorada, ou energizada por uma polêmica, cujo sentido assumido depende da posição do sujeito nos campos discursivos em disputa num dado evento polêmico (NASCIMENTO, 2018). 


\section{Conclusão}

Se tudo adquire sentido ao ser humano ao redor de "um centro concreto devalores queépensado, visto, amado" (BAKHTIN, 2010, p. 124), é a partir desse centro de amores que o homem age responsavelmente em relação ao outro, de maneira que a compreensão do dialogismo polêmico tem de ter isso em foco ao visar um sujeito polemizando. Como disse, é razoável afirmar que o ato de guerrear polemicamente pressupõe a reação a um valor amado que está ameaçado por um valor contrário, porquanto por um valor que se odeia por ameaçar o que se ama. Eis a polêmica numa visada dialógica e argumentativa.

Essa hipótese da polêmica como ódio velado ao valor do outro serviu de base para compreender, discursiva e argumentativamente, a divergência profunda entre afetivossexuais reformistas e cristãos tradicionalistas no espaço político brasileiro. Análises específicas não são o intento deste artigo teórico, porém, na tese de doutorado, mostrei abundantemente quais valores são amados e odiados por cada grupo e como isso fica evidente através dos argumentos mobilizados (NASCIMENTO, 2018).

Além disso, essa hipótese geral mostrou-se bastante produtiva e digna de ser aplicada no estudo de outras polêmicas, uma vez que sai do lugar comum a respeito da relação amor-ódio, ao trazer à tona uma visão mais antropológica do ser humano e do discurso argumentativo. Essa perspectiva possibilita, portanto, analisar a polemicidade nas diferentes estratégias argumentativas e ver como elas fazem sentido a cada sujeito posicionado em campos discursivos adversos, os quais impossibilitam, na maioria das vezes, a construção de um acordo, como foi o caso do Projeto de Lei anti-homofobia. Ademais, é claro, essa perspectiva dá relevo à discussão do dialogismo polêmico de Bakhtin, como já disse, pouco trabalhado, mas que merece muita atenção.

\section{Referências}

AMOSSY, Ruth. Apologia da polêmica. São Paulo: Contexto, 2017.

Apologie de la polémique. Paris: Presses Universitaires de France, 2014.

ANGENOT, Marc. Dialogues de sourds: traité de rhétorique antilogique. Paris: Mille et une nuits, 2008. $\overline{\text { Payot, } 1982 .}$

La Parole pamphlétaire: Typologie des discours modernes. Paris: 
V. $9(1)$

$151-169$

jan-abr

2019

O discurso social e as retóricas da incompreensão: consensos e conflitos na arte de (não) persuadir. São Carlos: EduFSCar, 2015.

ARISTÓTELES. Retórica. Trad. Marcelo Silvano Madeira. São Paulo: Riddel, 2007.

BAKHTIN, Mikhail (VOLOCHÍNOV). Marxismo e filosofia da linguagem. São Paulo: Hucitec, 2014.

BAKHTIN, Mikhail. Estética da criação verbal. Trad. Paulo Bezerra. São Paulo: Martins Fontes, 2011.

Para uma filosofia do ato responsável. Trad. Valdemir Miotello e Carlos A. Faraco. São Carlos: Pedro \& João editores, 2010.

Problemas da poética de Dostoiévski. Trad. Paulo Bezerra. Rio de Janeiro: Forense Universitária, 2013.

BRAIT, Beth; MACHADO, I. O encontro privilegiado entre Bakhtin e Dostoiévski num subsolo. Bakhtiniana, São Paulo, n. 6 v.1, p. 24-43, ago./dez., 2011.

BRASIL. SENADO FEDERAL DO BRASIL. COMISSÃO DE DIREITOS HUMANOS $(\mathrm{CDH})$. Audiência Pública: Ata da 96a reunião (extraordinária) da comissão permanente de direitos humanos e legislação participativa, da $1^{\text {a }}$ sessão

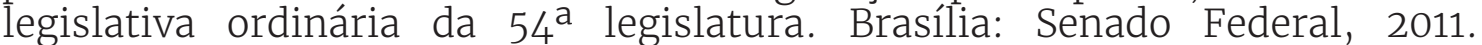
Disponível em <http://legis.senado.leg.br/sicon/index.html\#/pesquisa/lista/ documentos>. Acesso em 15 jul. 2014.

CLARK, K.; HOLQUIST, M. Mikhail Bakhtin. São Paulo: Perspectiva, 2004.

DAMÁSIO, A, R. El error de Descartes: la razón de las emociones. Barcelona: Editorial Andres Bello, 1999.

DUCROT, Oswald. Dizer e o dito. Campinas, SP: Pontes, 1987.

ANSCOMBRE, J.C. La argumentación en la lengua. Madrid: Editorial Gredos, 1994 [1988].

HERÁCLITO. Fragmentos contextualizados. Tradução, apresentação e comentários: Alexandre Costa. Rio de Janeiro: Difel, 2002.

MAINGUENEAU, Dominique. Gênese dos discursos. São Paulo: Parábola, 2008.

La sémantique de la polemique: discours religieux et ruptures idéologiques au XVII siècle. Lausanne: L'Age d'homme, 1983.

NASCIMENTO, Silva, Lucas. Análise dialógica da argumentação: a polêmica entre afetivossexuais reformistas e cristãos tradicionalistas no espaço político. 2018. 557f. (Doutorado em Língua e Cultura) - Instituto de Letras, Programa de PósGraduação em Língua e Cultura, Universidade Federal da Bahia, Salvador, 2018.

NEVES, Daniel Monteiro. Debates orais no Supremo Tribunal Federal: um modelo de interação polêmica. (Doutorado em Estudos Linguísticos) Programa de Pós-Graduação em Estudos Linguísticos (PosLin), Universidade Federal de Minas Gerais (UFMG), Belo Horizonte, 2017. 
ORECCHIONI, Catherine Kerbrat. La polémique et ses définitions. In: Gelas, NADINE; ORECCHIONI, C. K. Le Discours polémique. Lyon: P. U. V, 1980.

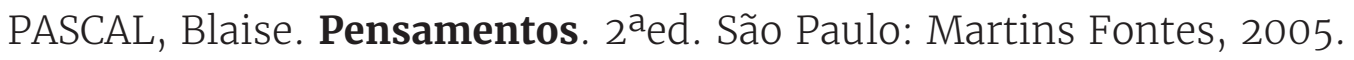

PERELMAN, Chaim; OLBRECHTS-TYTECA, Lucie. Tratado da argumentação: a nova retórica. Trad.s de Maria Ermantina de Almeida Prado Galvão. $2^{\mathrm{a}}$ ed. São Paulo: Martins Fontes, 2005.

PLANTIN, Christian. Des polémistes aux polémiqueurs. In: Declercq, GILLES; MURAT, Michel; DANGEL, Jacqueline. La parole polémique. Paris: Éditions Champion, 2003.

Les bonnes raisons des émotions: príncipes et méthode pour l'étude du discours émotionné. Bern: Peter Lang, 2011.

RABATEL, Alain. Homo Narrans: por uma abordagem enunciativa e interacionista da narrativa. Volume 1: Pontos de Vista e lógica da narração teoria e análise. São Paulo: Cortez, 2016.

SANTOS, Elmo. Enunciados d'Os Sertões. In: SANTOS, Elmo. Transdiscursividades: linguagem, teorias e análises. Salvador: EDUFBA, 2012.

SCHELER, Max. Esencia y forma de la simpatia. Buenos Aires: Editorial Losada, 1942.

Ética: nuevo ensaio de fundamentación de un personalismo ético. Madrid: Caparrós Editores, 2001.

Ordo amoris. Trad. Xavier Zubiri. Madrid: Caparros Editores, 2008.

SOWELL, Thomas. Conflito de visões: origens ideológicas das lutas políticas. São Paulo: É realizações, 2012.

TOULMIN, Sthephen. Os usos do argumento. São Paulo: Martins Fontes, 2006. 